\title{
Clinical and Experimental Studies on Myopathy in Cushing's Syndrome and Steroid Myopathy Report 1. Clinical Studies \\ Report 2. Experimental Studies
}

Seiya SAIKI, M.D.

2nd Department of Internal Medicine, Toho University School of Medicine, Tokyo, Japan

(Director : Professor Tatsuo Abe, M.D.)

Muscular weakness in Cushing's syndrome has been frequently observed, though adequate study on myopathy has only recently been made by Müller and his colleagues. Myopathies due to steroid administration such as cortisone, prednisolone, triamcinolone and dexamethasone in various diseases have been reported infrequently since clinical use of steroids has become prevalent in the past decade.

Four cases of myopathy in Cushing's syndrome and a case of steroid myopathy were studied clinically, histologically, biochemically and electromyographically. All these cases were characterized by weakness and atrophy of gluteal muscles and of lower limbs in moderate degrees. Occassionally, proximal muscle weakness of upper limbs with atrophy, and in a few instances, with distal muscle involvement was observed. Histological studies on biopsied specimens revealed edema, degeneration of various grades, atrophy of muscle fibers, increased sarcolemmal nuclei, increased connective tissue in interstitial tissue and some cell infiltration all of which suggest myopathic changes. Electromyographic studies demonstrated myogenic abnormality mostly in lower limbs and rarely in upper limbs. Biochemical studies in biopsied muscles revealed minimal changes on inorganic phosphorus, creatine phosphate, adenosine phosphate and creatine phosphokinase, though aldolase activity decreased significantly.

Experimental steroid myopathy was produced in rabbits by cortisone administration (10 mg per kilogram of body weight) for the purpose of pathogenetical study.

Marked loss of weight, increased excretion of creatine and striking degeneration of muscles were confirmed after administration of cortisone for a week or more. Creatine content in muscles of cortisone treated rabbits decreased by 16 per cent, though creatine phosphate did not fall significantly. However adenosine triphosphate and creatine phosphokinase activity decreased significantly by about 50 per cent and 37 per cent, respectively.

Occurrence of myopathy due to cortisone administration was not prevented by potassium chloride. However marked decrease in urinary creatine excretion occurred after potassium chloride ingestion. These data suggest the effect of potassium upon steroid myopathy in clinical treatment.

Biochemical analysis of muscles in experimental cortisone myopathy indicates that marked decrease of adenosine triphoapate and creatine phosphokinase may play an important role in the occurrence of myopathy.

(pp. $774 \sim 787$ )

Vol. 42 No. 7 


\title{
Cushing 症候群及び steroid myopathy に関する 臨床並びに実験的研究
}

\author{
第 2 編 動物実験編
}

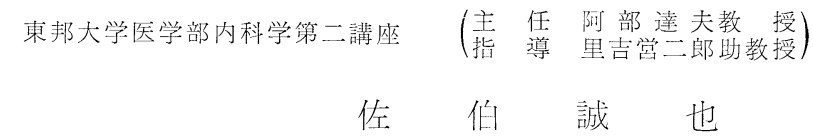

(昭和 41 年 1 月 19 日受付)

\section{1 緒言}

Cushing 症候群にみられる種々の臨床像が, glucocorticoid の多量分泌によつて起るととは, 既によく知 られているが，本症にみられる myopathy も同様の原因によるものであろう。事実本症の治療によつて myopathy 改善を示しているととは第1 編に述べた如くであり, glucocorticoid の大量投与によつて類似 の steroid myopathy の発生がみられている.

臨床例について諸種の面より検討した成績は既に第 1 編に述べたが，一般に Cushing 症候群や steroid myopathy は稀な疾患で，多数例について myopatny の発生機序を詳しく検討することは極めて困難であ る。したがつて人工的に steroid を大量投与して実験的な steroid myopathy を作成し，種及の検討を加え ることは, 本症の研究上極めて重要である.

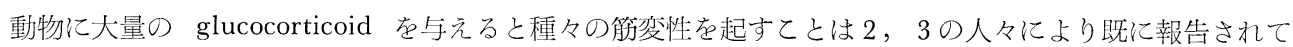
おり16 18)，Ellis ${ }^{17}$ ) は家鬼の実験的 coritsone myopathy について2，3の検討を加えている。著者も家鬼 で cortisone myopathy を作り, 病理学的及び生化学的な検討を加え, steroid myopathy の発生機序に関 して 2,3 の知見を得のでその成績を報告する.

\section{2 実験方法}

第 1 回実験：体重 $2 \mathrm{~kg}$ 前後の 18 羽の雄家鬼を 1 羽づつ採尿器付の飼育籠に入れ, 約 1 週間オリエンタル 鬼用固形飼料により飼育し，体重及び尿量を連続測定した上，1側四肢筋より，biopsy を行い，筋病理学的 所見及び筋中無機燐，クレアチン燐酸，ATP， aldolase 及びクレアチンフォスフォキナーゼ (CPK) の定量 を行つた。その後約 1 週間経過をみた上，cortisone acetate $10 \mathrm{mg} / \mathrm{kg} / \mathrm{day}$ （日本メルク万有）を連日 3 週間 皮下注射により投与し，体重及び尿量の連日測定を行つた後，再び対側の筋を biopsy し，病理学的所見及 び生化学的分析を行つた，次いで 6 羽住しては， cortisone acetate (以下 cortisone と略す) を更に 2 週 間投与すると同時に塩化カリウム $(\mathrm{KCl}) 500 \mathrm{mg} / \mathrm{day}$ を経口投与し，他の 6 羽に対しては KCl を投与せ ずに cortisone を同量 2 週間投与した。そ後脱血死を起させて筋の病理学的及び生化学的検討を行つた. 対照群 3 羽では蒸溜水を同様に注射し同様に測定を行つた (Fig. 1).

第 2 回実験：第 1 回実験と同様体重 $2 \mathrm{~kg}$ 前後の雄家后 12 羽を 1 週間飼育の後, 乙れを 2 群に分け, 実験 群 7 羽に対して cortisone $10 \mathrm{mg} / \mathrm{kg} /$ day 2 週間投与し，その間連日採尿し，尿中クレアチン及びクレアチ ニンの変動を観察し, 対照群 5 羽における変動と比較検討した。また 2 週間後に筋 biopsy を行い, 筋病理 
学的検索と同時に, 筋クレアチンの 定量を行つた。

第 3 回実験：前回同様体重 $2 \mathrm{~kg}$ 前 後の雄家鬼10羽に同量の cortisone を 2 週間投与し尿中クレアチン及び クレアチニンの変動を観察した後, $\mathrm{KCl} 500 \mathrm{mg} /$ day 経口投与と同時に cortisone $10 \mathrm{mg} / \mathrm{kg} / \mathrm{day}$ を更に 2 週 間投与し，尿中クレアチン及びクレ アチニンの変動を観察した。 また家 鬼10羽を $\mathrm{K}$ 欠乏食で飼育し，尿中ク レアチンの変動を 4 週間観察して cortisone 投与時のクレアチンの変 動と比較検討した.

測定方法 : 尿量は各飼育籠の採尿 管に排泄された24時間尿を毎日メス シリンダーで計測し, 尿中クレアチ

ンは Abelin の方法 ${ }^{19}$ ) クレアチニンはFolin の方法 ${ }^{20)}$, 無機燐は Martin-Doty の方法 ${ }^{11)}$, クレアチン燐酸 及び ATP は Allen の方法 ${ }^{12}$ によつて測定した. aldolase は Sibley-Lehninger 法 ${ }^{13}$, CPK は冲中らの方 法 ${ }^{14)}$ そり測定した。病理組織学的所見は biopsy 筋を直ちにアルコール及びホルマリンで固定した後, へ マトキシリンエオシン及び PAS 染色を行い検討した.

\section{3 実 験 成 績}

\section{1）体重, 筋菱縮及び尿量}

第 1 回の実験における cortisone 投与による体 重の変動はFig. 1 亿みられる如く, 投与後 4 乃至 7 日後には減少傾向を示し, 2 乃至 3 週後にはい ずれも cortisone 投与前の体重以下に減少する傾 向を示した．更に投与を続けると 6 乃至 7 週後に 著しいるいそうと筋力低下がおてり (Fig. 2)，一 部のもの（7 羽）は 4 乃至 7 週間で死亡するが, 4 週間以後ではその死亡率が極めて高くなる傾向 があつた。対照群では biopsy による一時的な体 重減少をみる他は漸次体重は増加し, 実験開始 4 乃至 5 日目で $3 \sim 3.2 \mathrm{~kg}$ 亿達している. cortisone 投与 4 週後に KCl を更に加えた症例では体重減 少が止まるもの，時には上昇するものも散見され たが，大多数は体重減少の傾向を示している．尿量の変化は Fig. 3 亿示す如くで対照群では 1 日100〜300cc の尿量を排泄しているのに対し， cortisone 投与群では投与開始後, 著しい尿量の排泄増加を示し, 時には $500 \mathrm{cc}$ 以上の排泄と摄取飲量の増加がみられた。 多飲及び尿量增加の傾向は投与開始後 1 週間が最も著しか つた. KCl 投与群と cortisone 単独投与群との間に差異はみられなかつた。

第 2 回及び第 3 回実験における体重の変動は何れも第 1 回実験と同様の体重変動を示した. K欠乏家鬼に おける尿量は対照群と差異がないが，体重は実験開始後約 I 週間で減少しはじめ，外見上明らかに筋の委縮 
が認められ，一部の動物は 7 乃至 1

Fig. 3. Changes in urinary excretion

日目に死亡し，残りも実験途次下痢 を伴つて死亡するものが多く実験を 完了しえたのは 3 羽にすぎなかつ た.

\section{2) 生化学的検討}

a) クレアチン代謝

尿中クレアチン及びクレアチニン の変動は Fig. 4, 5, 6 に示す如くで cortisone 投与開始後 2 日目より著 しい増加を示し, 投与前には20〜30 $\mathrm{mg} / \mathrm{day}$ の尿中クレアチンは時に

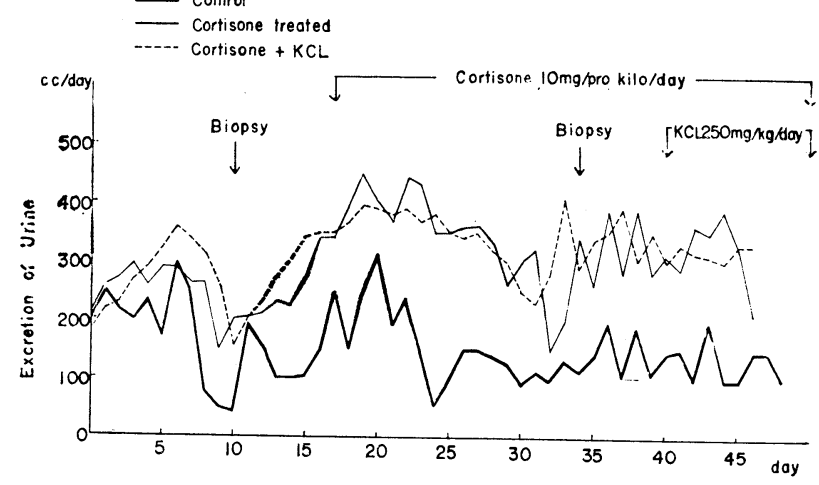

Fig. 4. Changes in urinary excretion of creatine and creatinine

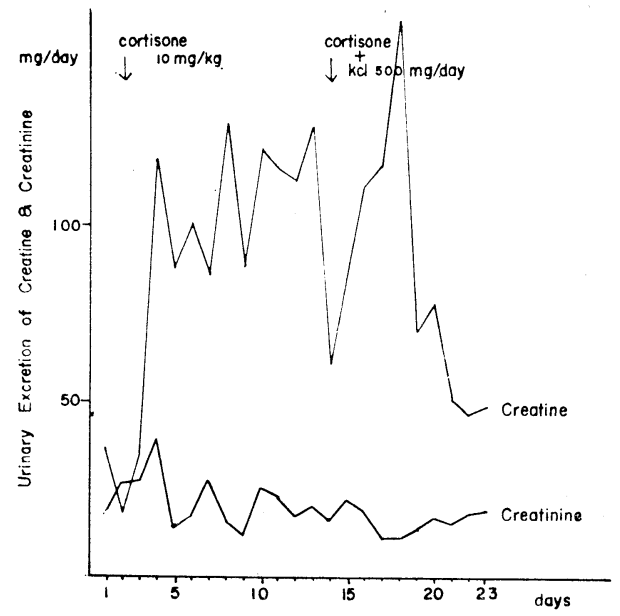

Fig. 5. Change in urinary excretion of creatine and creatinine (mean of 7 rabbits)

Fig. 6. Changes in urinary excretion of creatine in rabbits treated with cortisone or potassi. um-defficient diet
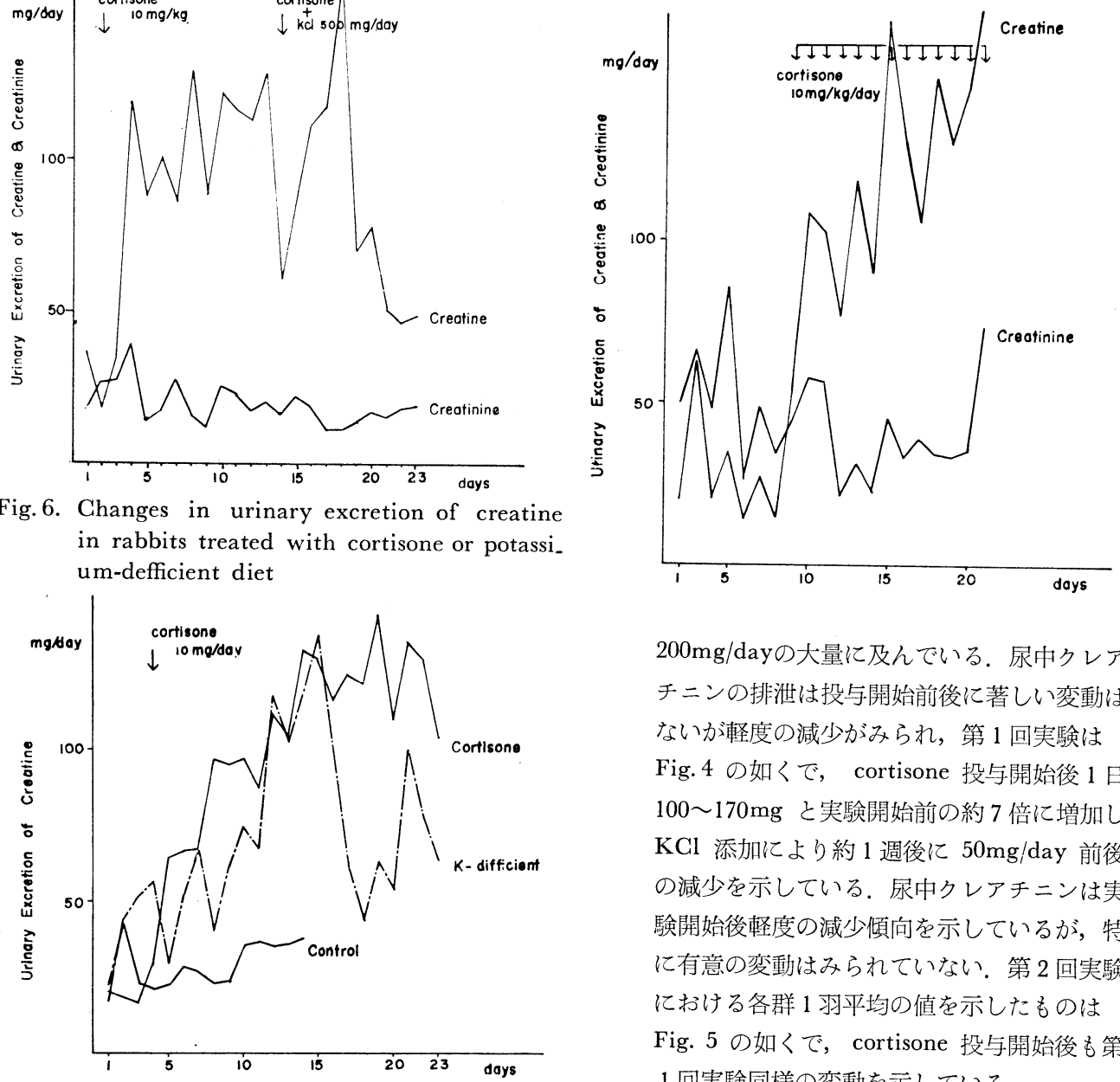

$200 \mathrm{mg} / \mathrm{day}$ の大量に及んでいる。尿中クレア チニンの排泄は投与開始前後に著しい変動は ないが軽度の減少がみられ，第 1 回実験は

Fig. 4 の如くで, cortisone 投与開始後 1 日 100 170mg と実験開始前の約 7 倍に増加し, $\mathrm{KGl}$ 添加により約 1 週後に $50 \mathrm{mg} /$ day 前後 の減少を示している，尿中クレアチニンは実 験開始後軽度の減少傾向を示しているが，特 に有意の変動はみられていない，第 2 回実験 における各群 1 羽平均の值を示したものは

Fig. 5 の如くで, cortisone 投与開始後も第 1 回実験同様の変動を示している. 
Cortisone 投与時と K欠炎家鬼の尿クレアチン 排澌とを比較検討した成績は Fig. 6 に示す如く

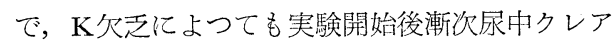
チンの排泄が増加し，約 2 週間後にピークに達す るが，その後はやや下降し50〜70mg/day の排泄 量を示しており, cortisone投与群よりも 2 週間後 は低值を示していた，生検筋のクレアチン量は Table 1 亿示す如くで，対照に比べ cortisone 投 与群は明らかに低下を示し，平均約16\%の有意の 減少が認められる。

b) 燐酸代謝

燐酸代謝の变動は Table 2, Fig. 7 亿示す如くで,
Table 1. Greatine con tent in muscles $(\mathrm{mg} / 100 \mathrm{~g}$ wet tissue)

\begin{tabular}{c|c}
\hline Control & Cortison treated group \\
\hline 390 & 376 \\
435 & 392 \\
415 & 425 \\
485 & 314 \\
385 & 330 \\
& 290 \\
& 330 \\
$421.0 \pm 41.7$ & $351.7 \pm 46.8$ \\
\hline
\end{tabular}

Table 2. Content of phosphorus and enzyme activity in muscles

\begin{tabular}{|c|c|c|c|c|c|}
\hline & & \multicolumn{2}{|c|}{$\begin{array}{l}\text { Control } \\
\text { group (18 rabbits) }\end{array}$} & & $\begin{array}{l}\text { Cortisone treated } \\
\text { group (11 rabbits) }\end{array}$ \\
\hline Inorganic $\mathrm{P}$ & $\mathrm{mg} / 100 \mathrm{~g}$ & \multicolumn{2}{|r|}{$12.1 \pm 3.1$} & \multicolumn{2}{|r|}{$16.9 \pm 3.1$} \\
\hline Creatine $\mathrm{P}$ & $\mathrm{mg} / 100 \mathrm{~g}$ & \multicolumn{2}{|r|}{$43.6 \pm 15.3$} & \multicolumn{2}{|r|}{$35.4 \pm 8.9$} \\
\hline ATP & $\mathrm{mg} / 100 \mathrm{~g}$ & $*$ & $51.8 \pm 10.0$ & $*$ & $24.4 \pm 6.4$ \\
\hline \multirow{2}{*}{\multicolumn{2}{|c|}{$\begin{array}{l}\text { Cretine- } \\
\text { phosphokinase } \mathrm{u} / \mathrm{g} / \mathrm{hr} \text {. } \\
\text { Aldolase } \quad \times 10^{3} \mathrm{u} / \mathrm{g} / \mathrm{hr} \text {. }\end{array}$}} & $* *$ & $142.1 \pm 24.3$ & \multirow[t]{2}{*}{$* *$} & $89.2 \pm 41.4$ \\
\hline & & & $56.5 \pm 18.7$ & & $46.4 \pm 24.3$ \\
\hline
\end{tabular}

$* \mathrm{P}<0.001 \quad * * \mathrm{P}<0.01$

Fig. 7. Inorganic phosphorus creatine phosphate and ATP in muscles

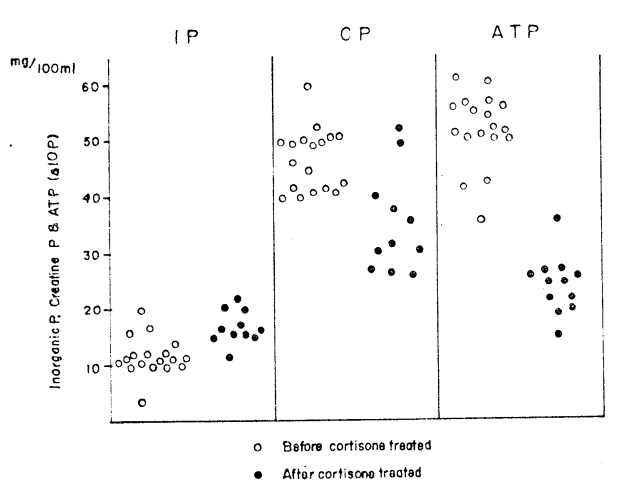

対照群即ち投与前の無機燐に比べて投与後の筋中 無機燐は差異が認められず，またクレアチン燐酸 は対照群に比べて軽度の低下を示すが，有意差は認められない。乙れに対して筋中 ATPは対照に比較して 著しい低下がみられ，約50\%の有意の減少が認められた。

c) 筋酵素活性
Fig. 8. Activities of aldolase and creatine phosphokinase (CPK) in muscles

$$
\text { CPK }
$$

Aldolose

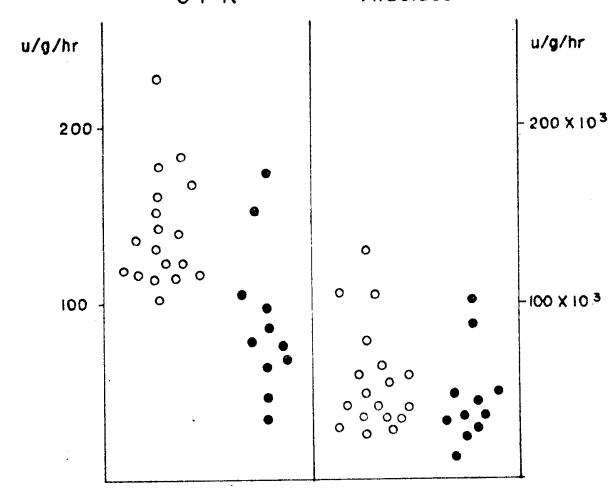

- Before cortisone treated

- After cortisone treated 
GPK 活性は対照群 $142.1 \pm 24.3 \mathrm{unit} / \mathrm{g} / \mathrm{hr}$ 湿重量に対して cortisone 投与群では $89.2 \pm 41.4 \mathrm{unit} / \mathrm{g} / \mathrm{hr}$ の值 を示し，推計学的には $1 \%$ 以下の危険率で有意差が認められた。解糖系酵素の一つである aldolase は対 照群 $56.5 \times 10^{3} \pm 18.7 \times 10^{3}$ に対して cortisone 投与群は $46.4 \times 10^{3}$ と有意差が認められなかつた (Fig. 8)

3) 病理組織学的所見

cortisone 投与の影響を組織学的にしらべた成績は Table 3 の如くで, 対照に比べて cortisone 投与 2 週 日及び 3 週目に何れも筋の浮腫，膨化及び均質化或は筋の萎縮が著しく認められる。また筋再生も約 $50 \%$

Table 3. Histological changes in cortisone treated rabbits - frequency of histological abnormality (\%) -

\begin{tabular}{lcccccc}
\hline $\begin{array}{l}\text { Histological } \\
\text { abnormality }\end{array}$ & Control & \multicolumn{2}{c}{$\begin{array}{c}\text { After treatment for } 2 \\
\text { weeks }\end{array}$} & $\begin{array}{c}\text { After Treatment for } 3 \\
\text { weeks }\end{array}$ \\
\hline Grade of abnormality & + & ++ & + & ++ & + \\
\hline Edema of Fibers & 0 & 0 & 64 & 30 & 64 & 35 \\
Swelling of fibers & 1.5 & 1.5 & 60 & 30 & 30 & 37 \\
Homogenization & 0 & 0 & 52 & 14 & 50 & 26 \\
Atrophy of muscles & 4.5 & 0 & 50 & 28 & 64 & 30 \\
Regenerative changes & 0 & 0 & 48 & 12 & 48 & 22 \\
Increase in sarcolemmal nuclei & 1.5 & 0 & 62 & 21 & 62 & 38 \\
Decrease in glycogen & 0.5 & 0 & 84 & 0 & 87 & 0 \\
Loss of cross striation & 0 & 0 & 84 & 0 & 92 & 0 \\
Increase of interstitial Tissue & 0 & 0 & 47 & 0 & 49 & 0 \\
\hline
\end{tabular}

認められ，顆粒状変性或は筋鞘核の増加も60\%以 上に認められている (Fig.9)。 また glycogen の 減少も対照群に比して何れも著明である。結合組 織の増生及び横紋の消失は高度に認められ，2 週 では84\%，3 週92\%に認められ，何れも筋原性の 著しい変化が認められている。一方 cortisone 投 与群を cortisone 投与と同時に KGl を投与した 群と比較したところ，てれらの組織学的変化は cortisone 単独投与に比べてやや変性が軽度にと どまり余り有意の改善はなかつた.

$$
4 \text { 考案 }
$$

steroid myopathy の報告は1958年 Dubois ${ }^{4}$ が 29例の Systemic Lupus Erythematosus の患者 に Triamcinolone を 1 週乃至 8 カ月投与し6例の myopathy の発現をみたのが最初で，次いで McLean ら ${ }^{5}$ も同様の経験をしている。 また Williams $ら^{6}$ は triamcinolone によつて起つた myopathy を, Kendall ら ${ }^{7}$ は triamcinolone を投与した47例中24例に myopathy が出現したととを報告している. Perkoff ら ${ }^{8}$ は cortisone 投与又は prednisolone 投与によつて, 血清クレアチンの上昇，クレアチン尿の出現，下肢の脱 力を報告しており，Golding $ら^{9)}$ Byers $ら^{10)}$ は dexamethasone により生じた myopathy を報告している. 本症の発現機序については未だ確実な成績は得られていないが，蛋白質の破壊促進を考えるものや，合成減 
少を推定するものがある22 24).

最近清水ら ${ }^{21}$ は副慜摘出ラッテで glycin $\mathrm{C}^{14}$ の筋蛋白への取込みが cortisone で抑制されるととを証明 し，骨格筋の蛋白合成を抑制したために myopathy の出現しうるてとを推定している。しかしながらてれ らの変化が myopathy の原因か結果かは容易に断定するてとは出来ない.

実験的な steroid myopathy は最初 Germuth ら ${ }^{16)}$ につて報告されたが，Ellis ${ }^{17)}$ は cortisone 投与家鬼の 筋を生化学的に測定し, 詳細な研究を行つている. Ellis ${ }^{17)}$ の成績では筋肉中の窒素が減少しないてと，また 脂肪， Na 及び水分は cortisone 投与家鬼で増加し，Kが減少するてとを確めている。 Ellis ${ }^{17}$ 便に cortisone 投与家鬼の K 減少が myopathy 発生の原因と考え，K欠乏動物を作り，全身の骨格筋，心筋の変化を steroid myopathy にわける変化と比較検討している．K欠乏家鬼においては骨格筋のみならず心筋の変性 もみられるのに反し， cortisone 家鬼では心筋変性のないととを認めており，更に cortisone 家鬼にKを添 加しても変性を予防しえないととを認めている。一方近年 Smith ${ }^{25)}$ は triamcinolone 家鬼で筋つォスフ オリラーゼ活性の減少するとと㸾めており，同様の成績は上村ら ${ }^{26)}$ とつても認められている，著者の実 験では cortisone 投与 $2 \sim 3$ 週以後に著明な体重減少, 筋菱縮, 筋力低下か認められ, また病理組織学的に も筋変性がみられることを確めえた，KGl 投与は cortisone 投与による体重減少を防ぎえず，また病理組 織学的の変化を改善しなかつたが，尿中クレアチンの変動をみると，cortisone 投与によつて起る著しいク レアチン尿が一過性に KCl 投与によつて抑制されることが認められている。この点からみると， cortisone myopathy の予防にはあまり効果がないが，KGI 投与は治療には少くとも有効であるととが推定できよう. KCl の影響は cortisone により生じた筋変性にともなう筋中Kの減少 ${ }^{17)}$ を防ぐために有効であるとも考元 られるので，K欠施が cortisone myopathy の一次的原因とする Ellis の結論からも KGl の有効性は支持 されるものであらう。

筋中の䤉素活性に対する変動も myopathy の原因として関係しているものか，或は結果としてみるべき かは極めて難しい問題であらう。解糖系の酵素であるフォスフォリラーゼの減少は既に報告されているが， 著者らの測定した解糖系䤉素 aldolase の変動は明らかでなかつた，従来報告された組織化学的な検討では， その醳素の絶対的增减を云々することは困難で，単に質的な比較にとどめるのが妥当であろう． Steroid myopathy が主として糖代謝代関係する glucocorticoid によつて起るてとは臨床的経験からも明らかである が，如何なる糖代謝の異常を介して myopathy を起すかは未だ明らかでない，一般的に myopathy では 血清 CPK 活性の上昇，また筋中 GPK 活性の減少するととがよく知られているが， cortisone 投与家鬼に おける筋中 CPK の特異な減少は myopathy の脱力及び筋萎縮と直接関係しているものと考えられる。乙 の成績は第 1 編に認められた患者の成績とは異つているが，動物と人間では醉素活性の強さ，分布が異つて おり，患者の筋にみられる成績と動物における成績が一致しないととは当然考朰れる。一方 CPK の関与 しているクレアチン燐酸及び ATP の変動は極めて明らかで，ATP は筋肉中で明らかに減少しており，ま た筋肉中クレアチン量も減少している。

筋肉中クレアチンの減少は尿中クレアチン増加に対応して生じた結果と思われるが，甲状腺中毒症などに みられる程著明ではない, cortisone myopathy では ATP の著しい減少によるエネルギー代謝の低下がお そらく myopathy の発生に重要な役割を果しているものと考えられる. glucocorticoid が如何なる代謝を 介しててれらの高エネルギー燐酸代謝系に作用しているかは未だ明らかでないが，糖代謝を介して間接的に 作用しているものであろう.

\section{結 論}

家鬼に cortisone を投与し病理組織学的変化, 尿中クレアチン, 筋中無機燐, クレアチン燐酸, ATP 及び aldolase, CPK の変動を観察し，また KCl 投与によるクレアチン代謝に対する影響を観察し次の結果を 得た.

1. cortisone 投与開始後 7 万至 24 日後には体重減少, 著明なクレアチン尿及び筋の変性が起ることを生 
化学的及び病理組織学的に確めた。

2. cortisone 投与家鬼では筋中クレアチンは対照群に比べ16\%の減少, 筋中クレアチン燐酸は軽度の低下 を，ATP は約50\%の低下を認めた。筋中 aldolose は減少が認められないが，筋中 CPK の活性は $37 \%$ の 有意の減少がみられた。

3. cortisone myopathy の発生は $\mathrm{KCl}$ 投与により予防できないが，尿中クレアチンの排泄は一時的に 抑制されるととが認められ，ての点から $\mathrm{KCl}$ 投与が有効作用することが推定される。

4. cortisone myopathy の発生に関し考察学加光，殊に ATP の著しい減少，クレアチンフォスフォキ ナーゼの低下から，エネルギー系代謝の低下が本症発現に関係が深いとと觉述べた。

稿を終るに臨み，御愁箵なる御指導，御校閲を睗わつた恩師阿部達夫教授に厚く感謝の意を表すると共に， 親しく御教示を頂いた里吉営二郎助教授及び川崎市立病院臨床検査科長西山保一先生に衰心より感謝いたし ます。また生化学的検索に御協力いただいた教室の古和久幸博士及び木下真男博士に深謝いたします。

\section{文献}

1) CUSHING, H. : Bull. Johns Hopkins Hosp., $50: 137$, (1932). TON, A.I., and RAGAN, C. : Amer. J. Med. 13 : 597, (1952). ERG, E. : J. Neurol. Neurosurg. \& Psychiat. 22 : 314, (1959).

2) PLOTZ, C.M., KNOWL-

3) MÜLLER, R. and KUGELB$167: 1590,(1958)$. 5) MAGLEAN, K. and SCHURR, P.H. : Lancet, $1: 701,(1959)$ WILLIAMS, R.S. : Lancet, $1: 698,(1959)$. 7) KENDALL, P.H. and HART, M.F. : Brit. Med. J., 1 : 682, (1959). 8) PERKOFF, G.T., SILBER, R., TYLER, F.H., CARTWRIGHT, G.E. and WINTROBE, M.M. : Amer. J. Med., 26 : 891, (1959). 9) GOLDING, D.N. and BEGG, T.B. : Brit. Med. J., $1: 1129$, (1960). 10) BYERS, R.K., BERGMAN, A.B. and JOSEPH, M.C. : Pediatrics, 29 : 26, (1962). 11) MARTIN, J.D. and DOTY, D.H. : Anal. Chem., $21: 965$, (1949). 12) ALLEN, R.J. L. : Biochem. J., 34 : 858, (1940). 13) SIBLEY, J.A. and LEHNINGER, A. : J. Biol. Chem., 177 : 859, (1949). 14) OKINAKA, S., KUMAGAYA, H. and ASSOCIATES. : Arch. Neurol., $4: 520$, (1961). 15) SATOYOSHI, E., MURAKAMI, K. and ASSOCIATES. : Neurology, $13: 645$, (1963). 16) GERMUTH, F.G. JR., NADZEL. G.A., OTTINGER, B. and OYAMA, J. : Proc. Soc. Exp. Biol. \& Med., 76 : 177, (1951). 17) ELLIS, J.T. : Amer. J. Path., $32: 993$, (1956). 18) TUNCBAy, T.O., KETEL, W.B. and BOSHES, B. : Neurology, $15: 314$, (1965). 19) ABELIN, I. and RAAFLAUB, J. : Biochem. Ztschr., $323: 382$, (1952). 20) FOLIN, O. and WU, H. : J. Biol. Chem. $38: 81$, (1919). 21) SHIMIZU, C.S.N. and KAPLAN, S.A. : Endocrinology, $74: 709$ ，(1964)。22）西川，植田他：日本臨床，22:2517，(1964). 23) SOFFER, L.J. : Diseases of The Endocrine Glands. Lea \& Febiger. Philadelphia (1956). 24) LUKENS, F.D.W. : Medical Uses of Cortisone. Blakiston, New York, (1954). 25) SMITH, B. : Neurology, $14: 857$, (1964).

26）上村, 加藤, 永田, 祖父江 : 脳と神経, $17: 694$, （1965）。 